\title{
Implementation of the Ramsar Convention on South American wetlands: an update
}

This article was published in the following Dove Press journal:

Research and Reports in Biodiversity Studies

27 November 2015

Number of times this article has been viewed

\author{
Florian Wittmann' \\ Ethan Householder ${ }^{2,3}$ \\ Astrid de Oliveira \\ Wittmann ${ }^{4}$ \\ Aline Lopes ${ }^{2}$ \\ Wolfgang J Junk ${ }^{5}$ \\ Maria TF Piedade ${ }^{2}$ \\ 'Biogeochemistry Department, \\ Max Planck Institute for Chemistry, \\ Mainz, Germany; ${ }^{2}$ MAUA Working \\ Group, National Institute for Amazon \\ Research - INPA, Manaus, Brazil; \\ ${ }^{3}$ Botanical Research Institute of Texas, \\ Fort Worth, TX, USA; ${ }^{4}$ Institute for \\ Biological Sciences, Federal University \\ of Amazonas - UFAM, Manaus, \\ ${ }^{5}$ National Wetland Institute - INAU, \\ Cuiaba, Brazil
}

\begin{abstract}
This review presents the current knowledge regarding South American wetlands and summarizes major outcomes of the implementation of the Ramsar Convention on Wetlands of International Importance for the South American continent. South America is the wettest continent on Earth, with wetlands accounting for $\sim 20 \%$ of its area. Wetlands harbor an exceptional rich biodiversity also including many endemic plant and animal species. They provide numerous ecosystem services in terms of provisioning material goods, regulating biogeochemical cycles, providing habitat, sustaining cultural practices, and importantly, contributing to the maintenance and generation of regional biodiversity. Major threats to wetlands include agroindustrial expansion, deforestation, soil erosion, mining, pollution, inadequate resource use, and large infrastructural projects such as reservoir construction for hydropower. South American countries were slow in adopting definitions, delineations, and classifications of their wetlands and in inventorying wetlands according to their extent and ecological characteristics. However, Ramsar sites are increasing continuously in both numbers and extent, covering 113 sites, totaling an area of $\sim 373,000 \mathrm{~km}^{2}$. Threats to wetlands and Ramsar sites are ongoing, mainly because of the lack of specific national wetland policies, limited financial and human resources, general lack of infrastructure, and limited monitoring capacity. The process of changing perceptions on the value of wetlands and their ecosystem services is improving, but it could be hastened by improved infrastructure and cooperation between Ramsar sites, wetland scientists, and local stakeholders. Outreach to raise awareness of societies, administrators, and governments of the critical importance of wetlands continues to be a major challenge for the conservation of South American wetlands.
\end{abstract}

Keywords: hydropower, Ramsar sites, wetland classification, wetland inventories, conservation

\section{Introduction}

As one of the first modern global nature conservation treaties, the Ramsar Convention on Wetlands of International Importance was signed by representatives of 18 nations on February 3, 1971. All countries present in South America entered the Convention during the 1980s and 1990s, and with exception of British Guyana, designated at least one (Suriname) or two Ramsar sites.

Although by this time it had become widely accepted that at least the most important wetlands should be conserved, only a few countries worldwide were collecting or disseminating systematic information regarding the definition, location, size, and delineation of wetlands. Therefore, early in the development of Ramsar, it was agreed that nations would be required to perform national inventories to establish specific wetlands conservation programs. Once established, the wise use, management, and monitoring of the most important wetlands would become a central point of the implementation of the Convention. ${ }^{1}$
Correspondence: Florian Wittmann Biogeochemistry Department, Max Planck Institute for Chemistry, Hahn Meitner Weg I, 55I28 Mainz, Germany Email f-wittman@web.de License. The full terms of the license are available at http://creativecommons.org/licenses//by-nc/3.0/. Non-commercial uses of the work are permitted without any further (c) (1) () 2015 Wittmann et al. This work is published by Dove Medical Press Limited, and licensed under Creative Commons Attribution - Non Commercial (unported, v3.0) perision the scope of the License are administered by Dove Medical Press Limited. Information on how to request permission may be found at: http://www.dovepress.com/permissions.php 
The present paper reviews major outcomes of the implementation of the Ramsar Convention on the South American subcontinent. First, we present an overview on extent, types, major threats, and conservation status of South American wetlands. Second, we evaluate to what extent South American countries meet the requirements of the six major initial criteria of wetland conservation of international importance: 1) to provide a definition of wetlands, 2) to elaborate wetland classifications, 3 ) to evaluate wetland conditions, 4) to implement the wise use of wetlands, 5) to implement national policies for wetland conservation, and 6) to manage wetlands and to monitor wetland characteristics. We point out major findings and provide an outlook on ongoing activities and their possible impact on wetland conservation and management.

\section{Overview of the state of knowledge of South American wetlands Extent, types, and biodiversity of wetlands}

South America is the wettest continent on Earth, with wetlands covering $\sim 3$ million square kilometers or $\sim 20 \%$ of the continental area. ${ }^{2}$ South American wetlands occur in all major climate zones, ranging from moist equatorial to warm desert climates in the northern subcontinent, and from warm oceanic climates to tundra and permanently frozen climates in the south. South America hosts six of the ten largest rivers on Earth in terms of water discharge and drainage area. ${ }^{3}$ Its largest wetlands are associated with large tropical river systems, such as the Amazon, Orinoco, and Paraguay-Paraná Rivers (Figure 1). Periodically or permanently waterlogged wetlands that are not directly associated with rivers also cover vast areas in the Amazon, savannas, and steppes. Peat swamps occur in the Amazon region, in the savanna belt, and in high Andean habitats and boreal Patagonia. The Andes harbor many glacier-fed wetlands, permanent lakes, and brackish to hypersaline wetlands in semiarid and arid regions, up to altitudes of 4,000 m. Mangroves, mainly occurring along the Atlantic coast and river estuaries, cover an area of $>45,000 \mathrm{~km}^{2}$, corresponding to nearly one-third of the world's total mangrove area. ${ }^{4}$

Most South American wetlands are flood-pulsing systems ${ }^{5}$ that oscillate between a terrestrial and an aquatic phase because precipitation regimes have pronounced rainy and dry seasons during the year. As a result of variation in height, duration, and frequency of flood waters and its influence on decomposition, nutrient cycles, and primary and secondary productivity, the flood pulse exerts strong controls over the distribution of plants and animals living in the aquatic-terrestrial transition zone (ATTZ) and their life history traits. ${ }^{6}$ In tropical to subtropical regions, the flood pulses of large-river systems are monomodal and predictable in frequency, height, and duration, thus facilitating evolutionary adaptation of organisms to spatiotemporal dynamics of the ATTZ. Predictable flood pulses occur along most South American Mega Rivers, such as the Amazon River system, Orinoco, Magdalena, Paraguay-Paraná, and São Francisco. The annual flood pulses of these river systems also influence flood dynamics of large associated seasonal wetlands such as the Pantanal, Bananal, Llanos de Moxos, and Llanos del Orinoco. ${ }^{6}$ In high-order tributaries of large tropical rivers as well as in the smaller fluvial networks of subtropical-to-temperate latitudes, monomodal flood pulses are replaced by unpredictable, polymodal flood regimes that depend on local and regional rainfall events. In arid regions, such as the Northeastern Brazilian Caatinga, flood regimes can be pluriannual. Permanent wetlands with relatively stable water levels occur in interfluvial areas and peatlands of the Amazon and savanna regions, the Chaco, Andes, and Patagonia. Some semiarid and arid deserts in the Andes and their western foothills harbor mostly small but very important wetlands in terms of both biological and cultural diversity.

In general, wetlands harbor a large fraction of global biodiversity, and tropical wetlands in particular are considered biodiversity hotspots. ${ }^{7}$ Unfortunately, databases on species numbers in most taxa that occur in South American wetlands are incomplete, with new species being described continuously. Inventories of South American wetlands are hindered by their remote location, and sampling is therefore insufficient. Also, wetlands attract many terrestrial species that facultatively colonize wetlands (ie, vascular plant species), or that use wetlands temporarily or episodically for habitat and food source (ie, migratory birds, terrestrial mammals). The ephemeral nature of wetlands interactions with such a wide variety of species complicates the generation of complete species lists.

Of the 51 freshwater ecoregions present in South America, as defined by Abell et al, ${ }^{8}$ at least 19 contain $\geq 500$ freshwater fish species, with highest species richness in the Amazon basin, parts of the Brazilian Cerrado, and the Atlantic rainforest domain. The Amazon basin alone harbors $>3,000$ fish species, from which richness generally decreases with increasing latitude and altitude. Approximately 1,000 fish species have been recorded in the Orinoco basin, 600 species in the La Plata/Paraná-Paraguay basin, 150 species in the São Francisco basin, 64 species in the Andean Altiplano, and 17 species in Patagonia. ${ }^{9}$ The Amazon also 


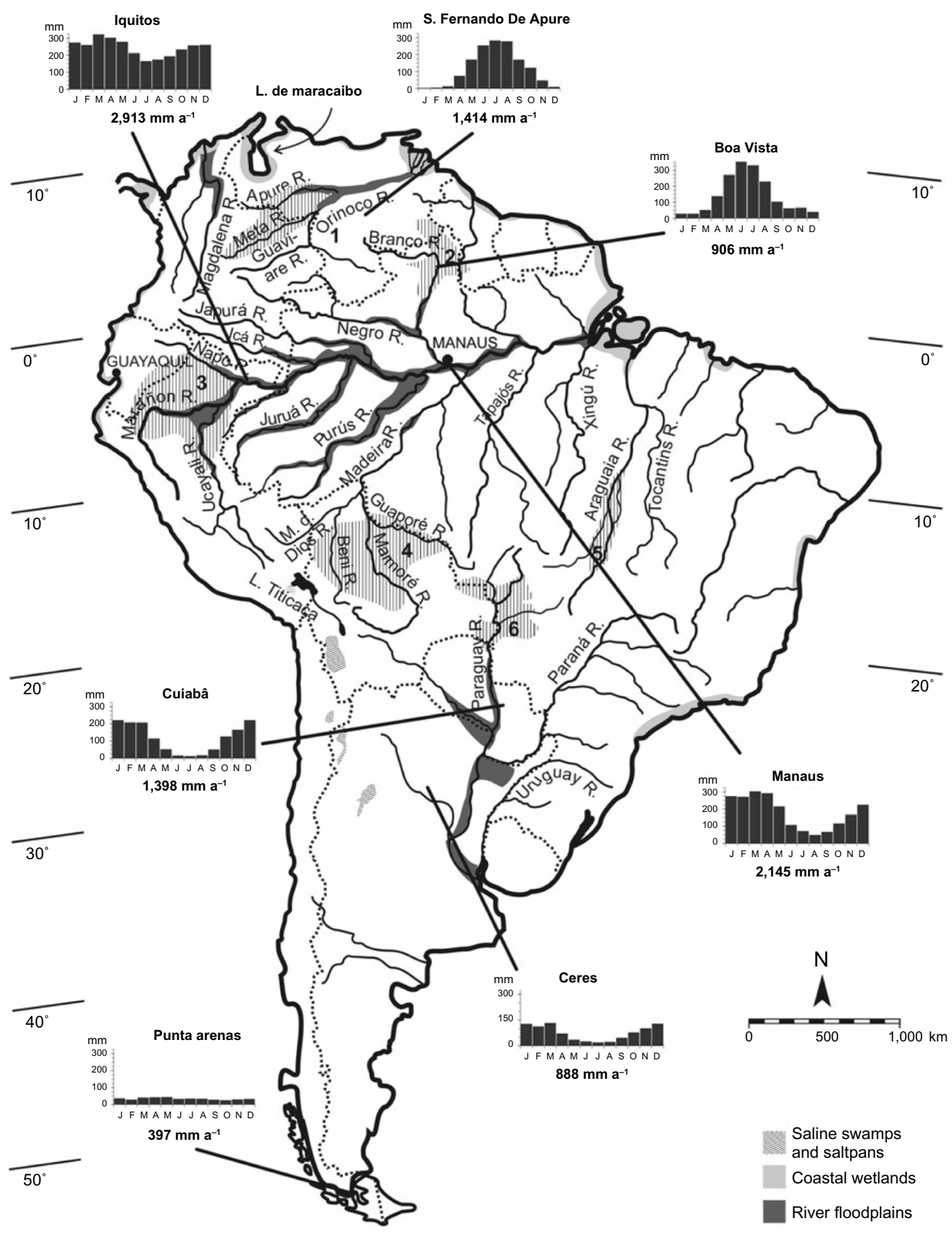

Figure I Annual rainfall pattern and distribution of major South American wetland types and wetlands.

Notes: I, Llanos del Orinoco; 2, periodically flooded savannas of Roraima and Rupuni; 3, Marañon-Ucayali palm swamps; 4, Llanos de Moxos; 5, periodically flooded savannas of the Araguaia River including Bananal; 6, Pantanal of Mato Grosso. With kind permission from Springer Science+Business Media: Aquatic Sciences, Current state of knowledge regarding South America wetlands and their future under global climate change, 75, 2013, II3-131, Junk WJ, Figure I. ${ }^{6}$

harbors the largest number of flood-tolerant tree species. Of the $\sim 5,000$ tree species with valid species names occurring in the Amazon basin, ${ }^{10} \sim 50 \%$ are able to colonize episodically, periodically, or permanently waterlogged soils (Wittmann et al, unpublished). In Amazonian whitewater river floodplains, $>1,000$ flood-tolerant tree species were recorded, ${ }^{11}$ whereas there are $\sim 600$ flood-tolerant tree species in Amazonian black-water floodplains. ${ }^{12}$ Tree species richness of wetlands decreases along both the geographic gradients $\mathrm{N}$ and $\mathrm{S}$ of the Amazon basin, but tree species diversity of individual wetlands may reveal high site-to-site variability according to local environmental constraints. Similar local variability in local site diversity has been reported in the Orinoco floodplains, ${ }^{13}$ the Pantanal, ${ }^{14}$ and the 
Llanos de Moxos, ${ }^{15}$ riparian forests of Colombian savannas, ${ }^{16}$ Cerrado, ${ }^{17}$ Caatinga, ${ }^{18}$ Chaco,${ }^{19}$ Atlantic rainforest (resumed by Wittmann ${ }^{20}$ ), subtropical to temperate grasslands, ${ }^{21}$ and in the Subantarctic-Patagonian transition zone. ${ }^{22}$ In contrast to richness patterns of trees, herbaceous hydrophytes are comparatively species poor in the Amazon where trees are the dominant life form. Thus, herbaceous hydrophytes show highest richness in wetlands of subtropical savannas such as the Pantanal ${ }^{23}$ and decline toward temperate latitudes.

Many South American wetlands contain endemic animal and plant species. The degree of species endemicity is generally attributed to the stability of wetlands on regional landscapes over evolutionary time scales and their ability to act as refuges. This is exemplified in the Amazon basin, where $\sim 10 \%-30 \%$ of the floodplain tree flora is geographically and ecologically restricted to this ecosystem. ${ }^{24}$ In contrast, endemic tree species in wetlands of the savanna belt are rare, ${ }^{16,25}$ attributable to intermittent periods of large-scale flooding and drought throughout past climate fluctuations that increased local extinction of wetland communities. ${ }^{24}$ On the other hand, the percentage of freshwater fish species endemism is generally high across South American freshwater ecoregions, accounting for $\geq 15 \%$ of the local fish fauna in most ecoregions, and reaching values of up to $70 \%$ of the local fish fauna in the northwestern part of Colombia, the eastern slope of the Bolivian Andes, and the northeastern and southeastern Atlantic rainforest domain. ${ }^{8}$

\section{Ecosystem services}

As elsewhere in the world, South American wetlands provide a variety of valuable ecosystem services ${ }^{26}$ in terms of provisioning material goods, regulating biogeochemical cycles, providing habitat, and sustaining cultural practices. ${ }^{27}$ After water used for agriculture, domestic, and industrial purposes, the most important provisioning services of South American wetlands are of food (ie, fish, fruits), raw materials such as timber, firewood, reed, and peat, as well as genetic, medicinal, and ornamental resources (Table 1). Many traditional people still live in or along South American wetlands, with many wetlands providing the basic resources for their existence and cultural integrity. Regulation of biogeochemical cycles includes services such as the maintenance of soil fertility, prevention against erosion, waste treatment, water purification, water flow control, and mitigation of natural flooding hazards. Regulation of atmospheric-wetland gas fluxes is especially important - positive and negative feedbacks to the climate system from the sequestration and emission of greenhouse gases are increasingly recognized to play a role in the regulation of local, regional, and even of global climate, as in the case of Amazonian wetlands (Table 1). Habitat services include gene pool protection of an exceptionally rich flora and fauna, as well as nursery services for wetland species, terrestrial species, and deep water species that use wetlands temporarily for habitat and food source. Finally, cultural services include recreation and tourism mainly for modern cultures and numerous spiritual uses for traditional cultures. ${ }^{27}$

One rarely mentioned ecosystem service of wetlands is their important contribution to the maintenance and generation of regional biodiversity. Wetland habitats often account for an important fraction of regional habitat heterogeneity within biomes. While their relatively small coverage within larger biogeographic units means that wetlands are generally not richer in species than adjacent uplands, they do harbor mostly different species than surrounding uplands and thus significantly contribute to beta-diversity. ${ }^{28}$ Many wetlands are integrated into larger fluvial networks that provide wet dispersal corridors, these often crossing climatically differentiated regions. ${ }^{29}$ As such, rivers may be important vectors of range expansion for many semiaquatic plant species as propagules are efficiently dispersed by water current and aquatic organisms. Perhaps more importantly, wetland microhabitats may serve as local refuges. By mitigating environmental stressors in otherwise inhospitable regions, wetland occupation can allow organisms to tolerate larger temperature ranges as well as maintain more favorable edaphic and moisture conditions compared to adjacent, terrestrial habitats. ${ }^{30}$ In this sense, over evolutionary time, wetlands are likely to have consisted of many habitats that have conveyed spatial and temporal resistance and/or resilience to populations of species living in constantly changing climatic contexts. ${ }^{31}$ For example, in periods of reduced water availability during the Tertiary and Quaternary, wetlands, and especially those along large rivers, played crucial roles as refugia for vascular plants and animals in tropical, subtropical, temperate, and boreal regions. In sum, flooding significantly alters local abiotic site conditions relative to surrounding uplands, thus providing novel circumstances for the potential colonization of species from different regions, or even for the evolutionary differentiation of new species.

\section{Scientific knowledge and research activities}

Research activities on South American wetlands are mostly undertaken by universities and research institutes. Despite 
Table I Most important provisioning and regulating ecosystem services of South American wetlands

\begin{tabular}{lll}
\hline Wetland type & Ecosystem services & Regulating services \\
\cline { 2 - 3 } & Provisioning services & Coast protection, carbon storage \\
\hline Coastal wetlands & $\begin{array}{l}\text { Fish, seafood, timber, firewood, tools, } \\
\text { handcraft, medical products }\end{array}$ & Stream bed stabilization, discharge buffering, groundwater \\
Seasonally flooded river & Water, fish, game animals, timber, firewood, & recharge, water purification, sediment retention, soil \\
floodplains & construction material, tools, fruits, handcraft, & fertilization, carbon storage, regional climate regulation \\
Episodically flooded riparian & medical products & Stream bed stabilization, discharge buffering, groundwater \\
wetlands & construction material, tools, fruits, handcraft, & recharge, water purification, sediment retention, soil \\
Permanently flooded swamps & medical products & fertilization, carbon storage \\
and peat swamps & Water, fish, game animals, timber, firewood, & Stream bed stabilization, discharge buffering, groundwater \\
& peat, reed, construction material, tools, & recharge, water purification, carbon storage \\
Saline inland wetlands & fruits, handcraft, medical products & Salt for industrial and domestic use
\end{tabular}

Notes: All wetlands in addition offer important habitat services as they maintain biodiversity and act as wildlife nursery for aquatic and semiaquatic organisms, as well as for terrestrial organisms that use wetlands temporarily as habitat and food source. All wetland types offer cultural services promoting tourism and recreation of traditional and modern societies.

increasing research infrastructure, activities still mostly concentrate on few wetlands, and national research programs specifically directed toward wetlands are sparse. ${ }^{2}$ Meanwhile, the perception of societies on ecosystem services and values of wetlands is continuously improving as a result of increased conservation efforts at regional, national, and global levels, improved transfer of knowledge, and increased awareness of societies of vulnerability to natural hazards related to global change, such as catastrophic droughts and floods. There is a considerable amount of scientific literature and knowledge concerning some South American wetlands, such as the Orinoco and Amazon River floodplains, the Pantanal, Bolivian Llanos de Moxos, Paraná River floodplains, Atlantic coastal systems, and Patagonian wetlands (resumed by Junk ${ }^{6}$ ), while other wetlands are poorly studied or not studied at all. In general, however, research activity on wetlands is still low when compared to that of terrestrial landscapes. This can be traced to the fact that many wetlands are remote and often located far away from the centers of population concentration and urban development, and thus also far away from research institutions and universities. The high abundance of water in many regions of South America, a general lack of national definitions of wetland habitats and their resources, as well as the cost-intensive logistics of wetland research in comparison to research in terrestrial ecosystems may represent important reasons for the comparatively low research effort on wetlands.

\section{Major threats}

Because population density in South America is mostly concentrated along the coastlines and in megacities, many remote inland wetlands are still in a fairly pristine stage. However, in less populated areas, major threats to wetlands include agroindustrial expansion, deforestation, soil erosion, pollution, mining, inadequate resource use, and large infrastructural projects such as reservoir construction for hydropower, river channeling, road constructions, and navigation. Considering that most South American cities do not have efficient wastewater treatment, industrial and domestic water pollution by liquids and solids is a common phenomenon in and near urban areas. In contrast, the use of fertilizers and pesticides pollutes many wetlands in rural areas. For example, in Brazil, the use of fertilizers increased from 1 to 8 million tons between 1970 and $2002,{ }^{32}$ and their use per area doubled from 80 to $160 \mathrm{~kg} \mathrm{ha}^{-1}$ between 1992 and 2012.33 The application of pesticides adds an additional $3.5 \mathrm{~kg}$ of petrochemicals per hectare. These striking numbers make Brazil the worldwide leader in the use of fertilizers and agro-toxic products per capita and per area. ${ }^{33}$ Unfortunately, the impact of pollution on water quality, wetland biota, ecosystem functioning, and human health is rarely investigated and still widely ignored by regional and national governments.

The transformation of natural vegetation into cropland monocultures and urban areas is an increasingly recognized threat to many South American wetlands, and is of particular interest because wetlands affected by these activities lose their natural capacity to provide important ecosystem services. Most large-river floodplains fall periodically dry for several months and are therefore often still considered as terrestrial ecosystems for agro-industrial use, thereby leading to wetland habitat destruction or degradation down to the stream's edge. The implementation of the new 
Brazilian "forest code" in 2012 legally expanded the area for agricultural use in wetlands, because the permanent protection zone of wetlands was significantly reduced. ${ }^{34}$ Heavily modified wetlands show a reduced buffer capacity for water storage, and thus react more quickly to naturally occurring drought and humid climate cycles. This was recently painfully experienced by the lack of water in critical reservoirs providing water to the Brazilian megacity, São Paulo, during the summers of 2014 and 2015. More than 9 million inhabitants were temporarily affected by drastic water shortage and rationing. At the same time, increasing numbers of flash floods in urbanized watersheds after heavy rainfall events have led to more catastrophic inundations in densely populated areas with impacts on inhabitants and economies. In rural areas, exceptional inundations lead to increased soil erosion, negatively affecting humus layers and soil nutrient contents, thus reducing the natural capacity of soils for food production and further increasing dependence on petrochemicals.

River damming and the construction of reservoirs for hydropower generation is another notable threat to many South American wetlands. While national policies still regard hydropower as a low-cost and "green" energy source, many reservoirs are located far away from where energy consumption is needed and often operate significantly below initially designed energy outputs. ${ }^{35}$ The construction of large reservoirs in South America is often supported by international investors, and economic arguments often outweigh environmental arguments in political debates. Although the construction of large river dams is usually accompanied by studies of environmental impact, these concentrate on the floodable area of the reservoir itself and largely ignore possible environmental impacts far up and down the river. Modified flood regimes, sediment and nutrient trapping, and the loss of hydro-ecological connectivity significantly affect the flora and fauna of dammed rivers well beyond the limits of the artificial reservoir itself, as demonstrated by numerous publications in South America and elsewhere. ${ }^{36,37}$ In addition to the existing 48 river dams in Amazonia, the construction of $>150$ dams has already been planned. Approximately one-third of the planned dams are estimated to have high ecological impact, resulting in loss of hydrological connectivity, increased forest fragmentation, and deforestation by means of construction of roads and transmission lines. ${ }^{37}$ The construction of these dams in Amazonia will negatively affect the biodiversity and value of ecosystem services provided by the largest and most pristine freshwater wetland system on Earth.
There are many additional threats to South American wetlands. Artificial flood control measures, such as flood dikes in urban areas, interrupt lateral connectivity to the uplands and negatively affect natural hydraulic and sedimentation processes. Pollution associated with hydrocarbon mining in Brazil and Venezuela, aluminum mining in Brazil, and gold mining in the Amazon basin is an important local threat. Aquacultural activities and related habitat destruction and pollution are affecting mangroves and many freshwater wetlands. The introduction of exotic fish, parasites, and weed species can negatively affect native biodiversity and result in economic loss when these species become invasive. ${ }^{6}$ Unmanaged or predatory forms of tourism are also threats to selected wetlands and wetland organisms. ${ }^{38}$

Global climate change will affect South American wetlands to different degrees. Considerable changes in wetland area are expected due to rising sea levels and changes in amount, seasonality, and distribution of precipitation patterns in most parts of the South American continent, as predicted by the Intergovernmental Panel on Climate Change. ${ }^{39}$ Ecologically intact wetlands will play an outstanding role in buffering the expected changes in the hydrological cycle and in reducing their social and economic impacts. ${ }^{2,6}$

\section{Overview of the implementation of the Ramsar Convention in South America}

Since the second Ramsar Conference of the Parties (COPs) in 1984 in Groningen, the Netherlands, COPs are held every 3 years at different locations of the contracting parties. COPs are valuable meetings where information is gathered regarding the state of the art of Ramsar-related activities, unifying information from individual national reports of participating countries. The last COP (COP12) was held in June 2015 in Punta del Este, Uruguay, the first meeting to be held on the South American continent. The national reports are available at http://www.ramsar.org/library/field date/2015/field document type/contracting-party-documents-418, published on 2 January 2015. Specific reports of the recent COP12 are available at http://www.ramsar.org/event/12th-meetingof-the-conference-of-the-parties, published between 27 February and 18 June 2015.

While COP12 reports promising increase in the numbers of wetland inventories, implementation of national wetlands monitoring programs, and wetland conservation efforts worldwide, most South American nations still have not adopted specific wetland definitions, and show serious deficits in the development of complete wetland inventories, 
classification systems, and management plans. ${ }^{40}$ This is exemplified in the following.

\section{Wetland definition, classification, and inventories}

South American countries were very slow to adopt specific definitions and delineations of their wetlands, a situation further exacerbated by the lack of inventories and classification schemes, which remain at unsatisfactory stages. The first attempt to list inventories of Central American and South American wetlands was published in the 1986 "Directory of Neotropical wetlands" by the International Wetland Research Bureau. Wetland inventories and classification systems of South American wetlands produced by the scientific community continue to grow, expanding knowledge of wetlands systems and guiding appropriate management proposals. The ongoing designation of new Ramsar sites is a positive trend that will result in improved knowledge regarding South American wetlands, their classification, and extent. In general, Ramsar designation has proven to be a powerful tool to encourage local and national governments to complete wetland inventories.

Examples of classifications of South American wetlands include those of Neiff ${ }^{41}$ and Brinson and Malvárez, ${ }^{42}$ who defined nine major wetland types in Argentina using hierarchical classification concepts. Using a combination of factor, discriminant, and cluster analyses, Clausen et $\mathrm{al}^{43}$ classified nine wetland types based on the vegetation of the Torres del Paine National Park in Patagonia, Chile. Kjerfve and Lacerda ${ }^{44}$ classified the most important mangrove habitats along the tropical regions of the Brazilian coast. Classifications exist for permanent swamps of the Brazilian Cerrado, ${ }^{45}$ parts of the semiarid northeastern Caatinga, ${ }^{46}$ the Brazilian Pampas, ${ }^{47}$ and the Paraná River floodplain. ${ }^{48}$ More recently, Junk et $\mathrm{al}^{40}$ developed a classification of Amazonian wetland types, based on climatic, hydrological, hydrochemical, and botanical parameters, defining 14 major wetland types. The same approach was applied to classify the most important habitat types of the Brazilian Pantanal. ${ }^{49}$ Amazonian white-water and blackwater river floodplains were classified by Junk et al, ${ }^{50,51}$ followed by a national definition, delineation, and classification of Brazilian wetlands. ${ }^{52}$ This classification was recently accepted by the Brazilian Council on Wetlands (CNZU) of the federal Ministry of Environment (MMA) for use in future efforts toward a nation-wide definition, delineation, and classification of Brazilian wetlands and their conservation. Because Brazil covers climate zones ranging from tropical to temperate latitudes, this definition covers most of South American wetland types, and could easily be adapted to the entire continent by incorporating Andean and boreal wetland habitats. As knowledge on the diversity of wetland habitats increases, the proposed classification system is able to accommodate the inclusion of new habitats, ecotones, and ecosystems at all hierarchical levels, including extratropical wetlands:

Wetlands are ecosystems at the interface between aquatic and terrestrial environments; they maybe continental or coastal, natural or artificial, permanently or periodically inundated by shallow water or consist of waterlogged soils. Their waters maybe fresh or highly or mildly saline. Wetlands are home to specific plant and animal communities adapted to their hydrological dynamics. The extent of a wetland can be determined by the border of the permanently flooded or waterlogged area, or in the case of fluctuating water levels, by the limit of the area influenced during the mean maximum flood. The outer borders of wetlands are indicated by the absence of hydromorphic soils and/or hydrophytes and/or specific woody species tolerant to grow in periodically or permanently flooded or waterlogged soils. The definition of a wetland area should include, if present, internal permanently dry areas as these habitats are of fundamental importance to the maintenance of the functional integrity and biodiversity of the respective wetland. ${ }^{52}$

The delimitation of Brazilian wetlands sensu Junk et a ${ }^{52}$ considers two new aspects that were lacking in most former wetland delimitations: 1) Wetlands are defined by using the mean maximum flood as delimitation criteria. This avoids the inadequate colonization of wetlands, thus providing a catastrophe limit for societies and economies. 2) The inclusion of wetland-intern permanently dry areas. This secures wetland connectivity to terrestrial areas and helps in maintaining functional integrity of environmental processes and wetland biodiversity.

\section{The Ramsar sites}

Currently, there are 113 Ramsar sites located on the South American continent, including the Caribbean State of Trinidad and Tobago, totaling an area of $\sim 373,000 \mathrm{~km}^{2}$. The area covered by Ramsar sites currently corresponds to $\sim 12.4 \%$ of the estimated area of wetlands on the South American continent ( $\sim 3$ million square kilometers $\left.{ }^{2}\right)$, but this estimate is subject to constant revision as the number and areal extent of Ramsar sites in South America continuously increase with new designations (Figure 2). 


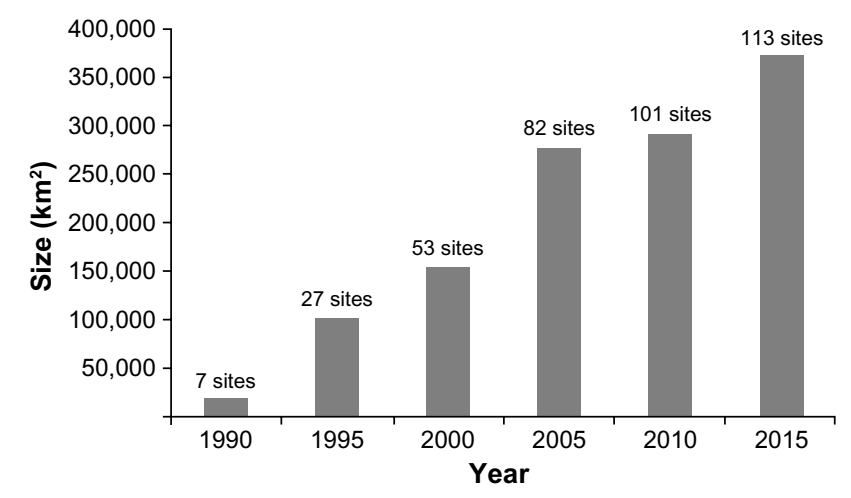

Figure 2 Number and size of Ramsar sites in South America (including Trinidad and Tobago) during the period 1990-2015.

Data from Ramsar. ${ }^{38}$

The number, extent, and habitat information of Ramsar sites are listed in Table 2 . The Ramsar sites vary considerably in abiotic and biotic conditions, size, climate zone, ecological status, threats, and selection criteria. They include ten marine sites, 39 coastal sites, and 74 inland sites. Sizes of Ramsar sites vary from 34 hectares (Laguna Conchali, Chile) to 3.8 million hectares (Abanico del Rio Pastaza, Peru). Eightynine sites are located within tropical and subtropical climate zones, divided into moist broadleaf forest (30 sites), dry broadleaf forest (18 sites), grasslands, savannas and shrublands (eleven sites), montane grasslands and shrublands (26 sites), and deserts and xeric shrublands (four sites). Temperate climate zones harbor a total of 20 sites, divided into flooded grasslands of the temperate evergreen forest (eight sites), grasslands of the steppe to cold deserts (eight sites), and nemoral broadleaf deciduous forest (four sites). Only one site is located in Mediterranean forest, woodlands, and shrubs (chaparral). Lowland sites with brackish to saline conditions (ie, estuarine systems, coastal areas, lagoons, salt marshes) include the largest fraction of sites, followed by lowland sites with freshwater conditions (floodplains, swamps), Andean sites with freshwater conditions (glacier-fed wetlands, lakes, swamps, creeks), and Andean sites with brackish to saline conditions (salt marshes, salt pans).

In 2013, Bolivia designated an area of $\sim 6.9$ million hectares of wetlands along the Blanco, Mata, and Yata Rivers as Wetlands of International Importance. The country currently boasts the largest wetland area designated under the Convention. ${ }^{37}$ With the inclusion of the Bolivian sites, the total area of Ramsar sites in Amazonia is $142.618 \mathrm{~km}^{2}$, distributed over nine sites. This represents $\sim 14 \%$ of the estimated area of Amazonian wetlands ( $\sim 1$ million square kilometers $\left.{ }^{40}\right)$, and $38.2 \%$ of the total area of Ramsar sites on the South American continent. Ramsar sites containing mangroves and coral reefs also increased during the last 3-year period. Currently, coastal and marine sites include at least six sites with coral reefs and 20 sites containing mangroves.

Most Ramsar sites are partially or entirely protected within larger conservation units. Thirty-one sites are protected in National Parks or Reserves, another 24 belong to conservation units with partial or total protection of their environmental and biological diversity, including Biosphere, Ecological and Fauna Reserves, Provincial and State Parks, and other types of protective reserves. Six Ramsar sites are privately owned and protected. Only 35 Ramsar sites are without any national or local protection.

Threats to Ramsar sites are ongoing and are not limited to non-protected areas. The most frequently cited threat is the expansion of agricultural activities, including livestock rearing, cattle ranching, and overgrazing, which affect a total of 34 Ramsar sites (including 20 sites with some status of protection). Illegal fishing and aquacultural activities such as shrimp farming affect a total of 23 sites (including 15 protected sites), while poaching, illegal hunting, and the exploitation of turtle and bird eggs endanger wetlands biodiversity in at least 17 sites (including 13 protected sites). Deforestation, mangrove felling, and the extraction of timber or firewood are reported for ten sites (including five protected sites). Other, less frequently cited threats include uncontrolled tourism, mining, pollution by industrial and domestic wastewaters and ship ballast, the expansion of invasive fish and plant species (each four sites), overextraction of water, sand, or peat (four sites), and threats related to climate change such as increased drought, coral bleaching, and glacier melting (three sites). In addition, river channelization, flood control, and river damming for hydroelectric power plants affect all sites in large-river floodplains in the Amazon, Pantanal, and Llanos.

Implementation of management plans for Ramsar sites is increasing continuously. As reported in the national reports for COP12, most contracting countries have developed some form of management plan for at least some sites. Only Bolivia lacked any management plans for its Ramsar sites, and no information was available for Venezuela.

\section{National policies, wise use, management, and monitoring}

While most South American countries have established some form of environmental policy or have national programs that indirectly relate to wetlands - policies on water resource management, biodiversity and genetic resources, forests, sustainable development, fisheries, water sanitation, etc - only Chile, 


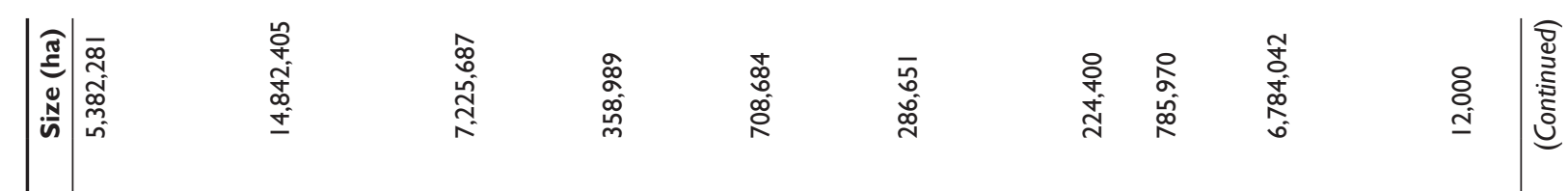

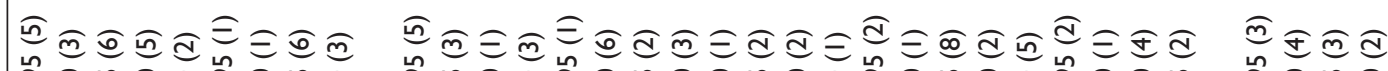

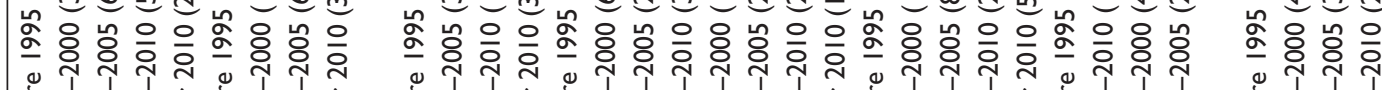

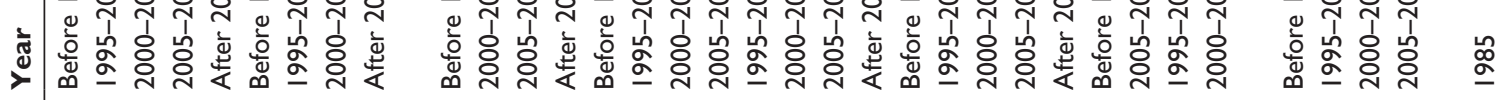

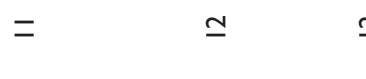

$\simeq$

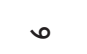

$\underline{\infty}$

$\frac{\frac{\pi}{0}}{\frac{0}{0}}$

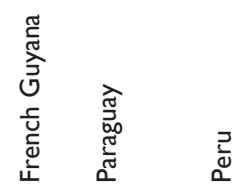

ڤั) 


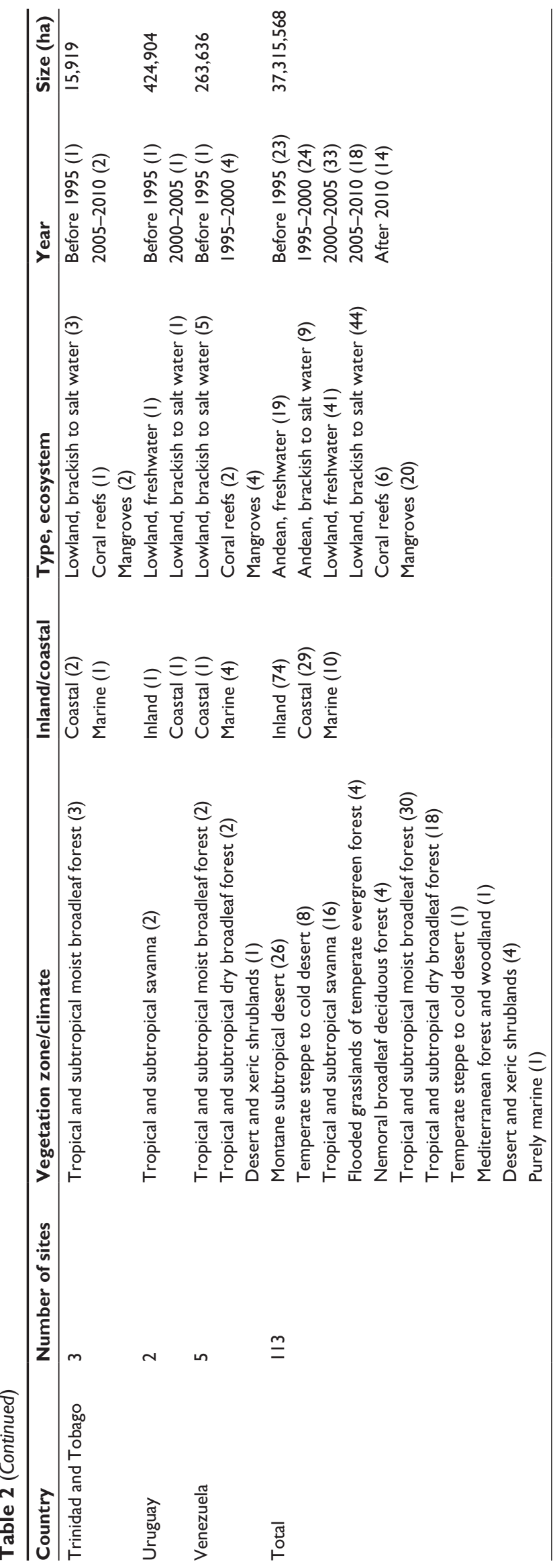

Peru, and Colombia have specific policies regarding wetlands at the national level. National wetlands policies are planned or in preparation for Suriname and Bolivia. Specific wetland regulations are essential to maintain the ecological integrity of a nation's wetlands and the ecological character of individual Ramsar sites. ${ }^{38}$ As reported by contracting parties in Ramsar COP12Doc.10, the lack of specific wetland regulations is one of the greatest difficulties in the implementation of criteria outlined by the Convention. ${ }^{38}$ Further exacerbating implementation is limited financial and human resources, general lack of infrastructure, and limited monitoring capacity.

Some contracting countries still have yet to establish a strategic monitoring system for their wetlands and Ramsar sites. Quantitative monitoring of environmental site conditions is mostly completely lacking, hindering the identification and valuation of ecosystem services provided by Ramsar sites. Moreover, most environmental or biological monitoring is not necessarily linked to wetlands but is part of broader conservation programs that may not be adequate for wetlands, or are aimed at individual populations of endangered animal species - especially waterfowl - that inhabit wetlands. Such a patch work of monitoring programs is of limited use in terms of understanding broad, long-term trends in the ecological and environmental health of the diversity of wetlands that occur within and across national boundaries. Limited monitoring in Argentina, Chile, Colombia, Ecuador, and Paraguay has led to reports of partial deterioration of the ecological character of some Ramsar sites, likely reflecting broader trends for most South American wetlands in the face of growing threats.

Only a few countries, such as Brazil and Peru, have national Ramsar or wetland committees. Therefore, Ramsar sites often suffer from the lack of coordination at the regional and national levels, weakening cooperation among sites and complicating the formulation of specific conservation strategies. However, regional and/or international initiatives and networks are increasing in number and reach, indicating the positive influence of the Ramsar Convention and associated societies, nongovernmental organizations, research institutes, etc, that work on conservation issues related to wetlands. Instructive models of international cooperation regarding wetland conservation include the Initiative for Conservation and Sustainable Use of High Andean Wetlands (seven South American countries and Costa Rica), the High Andean Flamenco's Network (four countries), the Initiative of the Caribbean Wetlands, the Initiative for the Conservation of Mangroves and Coral Reefs, the Initiative of the La Plata Basin, and the International Watershed Network between 
Colombia and Ecuador. Interest in establishing an initiative for integrated multinational actions regarding Amazonian wetland conservation is currently at a high point. ${ }^{38}$

\section{Conclusion}

Ongoing wetland loss and threats through pollution, water control projects, hydropower, and unsustainable resource management still endanger a large proportion of South American wetlands and the ecological, biological, and cultural diversity they help maintain. Many wetlands are still considered unproductive wastelands, and ecosystem services are not acknowledged by many South American societies and stakeholders. Information gaps regarding the importance of wetlands to global societal concerns will continue to lead to the ecological deterioration of many South American wetlands and stimulate further wetland loss throughout the following decades. Lack of a more holistic understanding of the societal benefits provided by wetlands accompanied by integrated conservation measures is likely to have irreparable consequences for biodiversity as well as human well-being. As one of the largest global nature conservation conventions, the Ramsar Convention plays an outstanding role in limiting, mitigating, and reversing wetland loss and degradation. This is exemplified in continuously increasing wetland inventories, classification schemes, Ramsar site designations, and regional and transnational cooperation and conservation efforts. While specific conservation efforts of wetlands were mostly local and isolated during the 1980s and 1990s, wetland conservation efforts in most South American contracting parties are now part of the daily routine of most national governments. The process of changing perceptions on the value of wetlands and their ecosystem services is ongoing, but it could be hastened by improved infrastructure and cooperation between Ramsar sites, wetland scientists, and local stakeholders. Outreach to raise awareness of societies, administrators, and governments of the critical importance of wetlands continues to be a major challenge for the conservation of South American wetlands and elsewhere.

\section{Acknowledgments}

The authors wish to thank the National Institute for Amazonian Research (INPA), MAUA Working Group PELD-MAUA and INPA/Max Planck Project in Manaus, and the Brazilian National Institute for Wetland Research (INAU), Cuiaba, for assistance.

\section{Disclosure}

The authors report no conflicts of interest in this work.

\section{References}

1. Matthews GVT. The Ramsar Convention on Wetlands: Its History and Development. Re-Issued 2013. Gland, Switzerland: Ramsar Convention Bureau; 1993.

2. Junk WJ, An S, Finlayson CM, et al. Current state of knowledge regarding the world's wetlands and their future under global climate change: a synthesis. Aquat Sci. 2013;5:151-167.

3. Latrubesse E. Patterns of anabranching channels: the ultimate end-member adjustment of mega rivers. Geomorphology. 2008;101:130-145.

4. Lacerda LD. Mangrove Ecosystems: Function and Management. Berlin: Springer; 2002.

5. Junk WJ, Bayley PB, Sparks RE. The flood pulse concept in river-floodplain systems. In: Dodge D, editor. Proceedings of the International Large River Symposium. Vol 106. Ottawa, Canada: Canadian Special Publications of Fisheries and Aquatic Sciences; 1989: 110-127.

6. Junk WJ. Current state of knowledge regarding South America wetlands and their future under global climate change. Aquat Sci. 2013;75: $113-131$.

7. Gopal B, Junk WJ, Davis JA, editors. Biodiversity in Wetlands: Assessment, Function and Conservation, Vol 1. Leiden, the Netherlands: Backhuys Publ; 2000.

8. Abell R, Thieme ML, Revenga C, et al. Freshwater ecoregions of the world: a new map of biogeographic units for freshwater biodiversity conservation. Bioscience. 2008;58:403-414.

9. Junk WJ. Freshwater fishes of South America: their biodiversity, fisheries, and habitats - a synthesis. Aquat Ecosyst Health Manag. 2007;10:228-242.

10. ter Steege H, Pitman NC, Sabatier D, et al. Hyper-dominance in the Amazonian tree flora. Science. 2013;342:325-334.

11. Wittmann F, Schöngart J, Montero JC, et al. Tree species composition and diversity gradients in white-water forests across the Amazon basin. J Biogeogr. 2006;33:1334-1347.

12. Wittmann F, Schöngart J, Junk WJ. Phytogeography, species diversity, community structure and dynamics of amazonian floodplain forests. In: Junk WJ, Piedade MTF, Wittmann F, Schöngart J, Parolin P, editors. Amazonian Floodplain Forests: Ecophysiology, Biodiversity and Sustainable Management. Ecological Studies 210. Heidelberg, Berlin, New York: Springer Verlag; 2010:61-104.

13. Godoy JR, Petts G, Salo J. Riparian flooded forests of the Orinoco and amazon basins: a comparative review. Biodivers Conserv. 1999;8: $551-586$.

14. Damasceno GA Jr, Semir J, Santos FAM, Leitão-Filho HF. Structure, distribution of species and inundation in a riparian forest of the Rio Paraguai, Pantanal, Brazil. Flora. 2005;200:119-135.

15. Jørgensen PM, Macía MJ, Fuentes A, et al. Lista anotada de las plantas vasculares registradas e la región de Madidi. Ecologia en Bolívia. 2005;40:70-169.

16. Veneklaas EJ, Fajardo A, Obregon S, Lozano J. Gallery forest types and their environmental correlates in a Colombian savanna landscape. Ecography. 2005;28:236-252.

17. Metzger JP, Bernacci LC, Goldenberg R. Pattern of tree species diversity in riparian forest fragments of different widths (SE Brazil). Plant Ecol. 1997;133:135-152.

18. Ratter JA, Bridgewater S, Ribeiro JF. Analysis of the floristic composition of the Brazilian Cerrado vegetation III: comparison of the woody vegetation of 376 areas. Edinb J Bot. 2003;60:57-109.

19. Cagnolo L, Cabido M, Valladares G. Plant species richness in the Chaco Serrano Woodland from Central Argentina: ecological traits and habitat fragmentation effects. Biol Conserv. 2006;132:510-519.

20. Wittmann F. Tree species composition and diversity in Brazilian freshwater floodplains. In: Pagano MC, editor. Mycorrhiza: Occurrence in Natural and Restored Environments. New York: Nova Science Publ; 2012:223-263.

21. Budke JC, Jarenkow JA, Oliveira-Filho AT. Relationships between tree component structure, topography and soils of a riverside forest, Rio Botucaraí, Southern Brazil. Plant Ecol. 2007;189:187-200. 
22. Speziale KL, Ruggiero A, Ezcurra C. Plant species richness-environment relationships across the Subantarctic-Patagonian transition zone. J Biogeogr. 2010;37:449-464.

23. Pott VJ, Pott A. Plantas aquáticas do Pantanal. Brazil: Embrapa. Brasilia. 2000:404.

24. Wittmann F, Householder E, Piedade MTF, et al. Habitat specifity, endemism and the neotropical distribution of amazonian white-water floodplain trees. Ecography. 2013;36:690-707.

25. Montes R, San José JJ. (1995) Vegetation and soil analyses of toposequences in the Orinoco llanos. Flora. 1995;190:1-33.

26. Costanza R, d'Arge R, de Groot R, et al. The value of the world's ecosystem service and natural capital. Nature. 1997;387:253-260.

27. De Groot R, Brander L, Van der Ploeg S, et al. Global estimates of the value of ecosystems and their services in monetary units. Ecosyst Serv. 2012;1:50-61.

28. Sabo JL, Sponseller R, Dixon M, et al. Riparian zones increase regional species richness by harboring different, not more, species. Ecology. 2005;86:56-62.

29. Naiman RJ, Décamps H, Pollock M. The role of riparian corridors in maintaining regional biodiversity. Ecol Appl. 1993;3:209-212.

30. Sculthorpe CD. The Biology of Aquatic Vascular Plants. Königstein, Germany: Koeltz Scientific Books; 1985.

31. Sedell JR, Reeves GH, Hower FR, Stanford JA, Hawkins CP. Role of refugia in recovery from disturbances: modern fragmented and disconnected river systems. Environ Manage. 1990;14:711-724.

32. Nicolella AC, Dragone DS, Bacha CJC. Determinantes da demanda de fertilizantes no Brasil no período de 1970 a 2002. Revista de Economia e Sociologia Rural. 2005;43:81-100.

33. IBGE. Indicadores de Desenvolvimento Sustentável, Estudos e Pesquisas Informação geográfica No 9. Rio de Janeiro: Instituto Brasileiro de Geografia e Estatística; 2012.

34. Sousa PT Jr, Piedade MTF, Candotti E. Brazil's forest code puts wetlands at risk. Letter to Nature. Nature. 2011;478:458.

35. Fearnside PM. Dams in the amazon: Belo Monte and Brazil's hydroelectric development of the Xingu River basin. Environ Manage. 2006;38:16-27.

36. Rosenberg DM, Bodaly RA, Usher PJ. Environmental and social impacts of large-scale hydroelectric development: who is listening? Global Environ Change. 1995;5:127-148.

37. Finer M, Jenkins CN. Proliferation of hydroelectric dams in the Andean Amazon and implications for Andes-Amazon connectivity. PlosOne. 2012; 7:e35126.

38. Ramsar. Regional Overview of the Implementation of the Convention and its Strategic Plan in the Americas (Neotropics and North-America regions). Gland, Switzerland: Ramsar COP12Doc.10; 2015.

39. Collins MR, Knutti J, Arblaster J-L, et al. Long-term Climate Change: Projections, Commitments and Irreversibility. In: Stocker TF, Qin D, Plattner G-K, et al, editors. Climate Change 2013: The Physical Science Basis. Contribution of Working Group I to the Fifth Assessment Report of the Intergovernmental Panel on Climate Change. Cambridge University Press, Cambridge, United Kingdom and New York, NY, USA, pp. 1029-1106.
40. Junk WJ, Piedade MTF, Schöngart J, Cohn-Haft M, Adeney JM, Wittmann F. A classification of major naturally-occurring Amazonian lowland wetlands. Wetlands. 2011;31:623-640.

41. Neiff JJ. Humedales de la Argentina: sinopsis, problemas y perspectivas futuras. In: Cirelli AF, editor. Funciones de los humedales, calidad de vida y agua segura. Buenos Aires: El agua en Iberoamérica, Publ. CYTED; 2001:83-112.

42. Brinson MM, Malvárez AI. Temperate freshwater wetlands: types, status, and threats. Environ Conserv. 2002;29:115-133.

43. Clausen JC, Ortega IM, Glaude CM, Relyea RA, Garay G, Guineo O. Classification of wetlands in a Patagonian National Park, Chile. Wetlands. 2006;26:217-229.

44. Kjerfve B, Lacerda LD. Mangroves of Brazil. In: Lacerda LD, editor. Conservation and Sustainable Utilization of Mangrove Forests in Latin America and Africa Regions. Vol 2 Part I - Latin America. Okinawa, Japan: Mangrove Ecosystems Technical Reports ITTO/ISME Project PD114/90 (F); 1993:245-272.

45. Ribeiro JF, Walter BMT. Fitofisionomias do bioma cerrado. In: Sano SM, Almeida SP, editors. Cerrado: ambiente e flora. Planaltina: EMBRAPA-CPAC; 1998:89-166.

46. Maltchik L, Costa MAJ, Duarte MCD. Inventory of Brazilian semiarid shallow lakes. Anais da Academia Brasileira de Ciências. 1999;71: 801-808.

47. Maltchik L, Rolon AS, Guadagnini DL, Stenert C. Wetlands of Rio Grande do Sul, Brazil: a classification with emphasis on plant communities. Acta Limnol Bras. 2004;16:137-151.

48. Thomaz SM, Agostinho AA, Hahn NS. The Upper Paraná River and its Floodplain: Physical Aspects, Ecology and Conservation. Leiden, the Netherlands: Backhuys Publishers; 2004.

49. Nunes da Cunha C, Junk WJ. A preliminary classification of habitats of the Pantanal of Mato Grosso and Mato Grosso do Sul, and its relation to national and international classification systems. In: Junk WJ, da Silva CJ, Nunes da Cunha C, Wantzen KM, editors. The Pantanal: Ecology, Biodiversity and Sustainable Management of a Large Neotropical Seasonal Wetland. Sofia, Moscow: Pensoft; 2011:127-142.

50. Junk WJ, Piedade MTF, Schöngart J, Wittmann F. A classification of major natural habitats of Amazonian whitewater river floodplains (várzeas). Wetlands Ecol Manage. 2012;20:461-475.

51. Junk WJ, Wittmann F, Schöngart J, Piedade MTF. A classification of the major habitats of Amazonian black-water river floodplains and a comparison with their white-water counterparts. Wetlands Ecol Manage. 2015;23(4):677-693.

52. Junk WJ, Piedade MTF, Wittmann F, et al. Brazilian wetlands: their definition, delineation and classification for research, sustainable management and protection. Aquatic Conserv. 2014;24:5-22.
Research and Reports in Biodiversity Studies

\section{Publish your work in this journal}

Research and Reports in Biodiversity Studies is an international, peerreviewed, open access journal publishing original research, reports, reviews and commentaries on all areas of biodiversity research. The manuscript management system is completely online and includes a

\section{Dovepress}

very quick and fair peer-review system. Visit http://www.dovepress.com/ testimonials.php to read real quotes from published authors. 